BLS 33, No 2 2007. DOI: http://dx.doi.org/10.3765/bls.v33i2.3504

(published by the Berkeley Linguistics Society and the Linguistic Society of America)

\title{
A Definite Mystery
}

\author{
PAMELA MUNRO \\ $U C L A$
}

Zapotec languages indicate tense, aspect, and modality with "aspect" prefixes on verbs. The most widely used of these prefixes mark Habitual, Perfective (or Completive), and Irrealis (or Potential), but a number of languages have additional, sometimes less well understood, aspect forms. In this paper I consider two similar Zapotec aspect markers, one indicating a definite future, the other (used only on motion verbs) with a quite different meaning. Are they one morpheme or two? It's a definite mystery-but my conclusion, based on both internal and comparative evidence, is that they are separate. ${ }^{1}$

\section{Introduction}

Tlacolula Valley Zapotec (TVZ; Ethnologue code ZAB) has been described as having seven aspects (Munro and Lopez, et al., 1999), illustrated in (1) for the verbs 'runs' and 'puts on (a shirt)'.

(1) Habitual: rzh:ùu'nny 'runs' Perfective: bzh:ùu'nny 'ran'

Progressive: cazh:ùu'nny 'is running' Neutral: Irrealis: yzh:ùu'nny 'will run' Subjunctive: nzh:ùu'nny '(if...) had run' Definite: $\quad$ x:ùu'nny 'will surely run' ra'ahcw 'puts on (a shirt)' gwu'aht 'put on (a shirt)' caya'ahcw 'is putting on (a shirt)' naa'cw 'is wearing (a shirt)' ga'acw 'will put on (a shirt)' nya'ahcw '(if...) had put on (a shirt)' za'ahcw 'will surely put on (a shirt)'

\footnotetext{
${ }^{1}$ The TVZ examples discussed here reflect the dialect of San Lucas Quiaviní (often called SLQZ): some were provided by my collaborator Felipe H. Lopez, who has graciously discussed all the issues I raise here; others come from a collection of texts about the immigration experience (Lopez and Munro, eds., in preparation). Great thanks also to Christopher Adam, Rosemary Beam de Azcona, Cheryl Black, John Foreman, Felicia Lee, Rosa María Rojas Torres, and Aaron Sonnenschein, who provided helpful data and discussion, as well as to Michael Galant, Brook Lillehaugen, Bernard Comrie, Alexandra Aikhenvald, and other members of the BLS audience and the UCLA American Indian Seminar for their helpful comments.
} 
The examples show both that the shape of many (boldfaced) aspect prefixes varies from verb to verb (conditioned both phonologically and lexically), and also that some aspects don't occur for all verbs.

The Definite proper, indicated by $z$ - before vowels and $s$ - (sometimes assimilated, as with 'will surely run' in (1)) before consonants, is a 'modal aspect' (Lee $1999,2006)$, used to specify futures that the speaker is certain will occur, as in (2) and (3). (All $z$-verbs are boldfaced in this paper, with their translations underlined. TVZ is a VSO language; subjects are indicated by nouns or names or by clitic pronouns.)

$$
\begin{array}{lll}
\text { Z-eheh } & \text { Jwaany } & \text { Ba'ahc. 'Juan will surely go to Tlacolula.', } \\
\text { def-go } & \text { Juan } & \text { Tlacolula } \\
\text { S-tòo'oh } & \text { Gye'eihlly } & \text { ca'rr. 'Mike will surely buy the car.' } \\
\text { def-buy } & \text { Mike } & \text { car }
\end{array}
$$

Such examples contrast with Irrealis sentences like those in (4)-(5); the Irrealis (which has many other modal uses) is a much more common way to show futures, but speakers describe these as less certain.

$$
\begin{aligned}
& \text { Ch-iia Jwaany Ba'ahc. 'Juan will go to Tlacolula.' } \\
& \text { irr-go Juan } \quad \text { Tlacolula } \\
& \text { Y-tòo'oh Gye'eihlly ca'rr. 'Mike will buy the car.' } \\
& \text { irr-buy Mike car }
\end{aligned}
$$

Another $z$ - prefix occurs only with a small set of motion verbs (in TVZ, these are rihah 'goes', rie'd 'comes', and rihah 'goes home', (paradigmatically distinct from 'goes')) in examples like (6). For now, I will gloss this second $z$-prefix as ' $z 2$ ', and will use that term to refer to such verbs for most of this paper.

$$
\begin{aligned}
& \text { Z-èe Jwaany Ba'ahc. 'Juan was going to Tlacolula.' } \\
& \text { z2-go Juan Tlacolula }
\end{aligned}
$$

Out of context, sentences like (6) typically have progressive translations; they strongly suggest a reference to going or coming only one way, without completing the trip. This progressive sense seems to fill an important gap in the aspectual paradigm shown in (1), since the three verbs of motion that can be used in with

\footnotetext{
${ }^{2}$ TVZ data is presented in the academic orthography of Munro and Lopez et al. (1999). Abbreviations used include an : animal, anap : anaphoric, and : andative, cop : copula, dct : deictic, def : definite, dst : distal, emph : emphatic, form : formal, hab : habitual, inf : informal, irr : irrealis, neut : neutral, opp.sex.sib : opposite sex sibling, perf : perfective, $\mathrm{pl}:$ plural, pron : pronoun base, prf : perfective, prg : progressive, prx : proximate, pt : point (second position negative), rsp : respectful, sbj : subjunctive, z2 : 'non-future definite'; person and number are shown with 1, 2, 3, $\mathrm{s}, \mathrm{p}$. Clitic boundaries are shown with $=$

${ }^{3}$ This verb can also express directed motion into other enclosed areas.
} 
the z2 prefix cannot be used with the Progressive $c a$ - prefix.

The $z$-prefixes in both (6) and (2) (as well as the $s$ - in (3)) have been called "Definite" (Lee 1999, 2006; Munro and Lopez, et al., 1999): Munro and Lopez et al. (1999) and Lee $(1999,2006)$ call the z2 form in (6) the "non-future Definite", 4 assuming it to reflect a separate but related use of the modal aspect prefix in (2). (I will refer to Definite proper forms like those in (2)-(3) as "future Definites" below to distinguish them from $\mathrm{z} 2$ forms.)

In contrast, in Munro (2006) I asserted that there are two forms involved (with the z2 form in (6) analyzed as non-modal); Munro, Lillehaugen, and Lopez (in preparation), a textbook currently being used in first-year Zapotec classes native speaker Felipe H. Lopez is teaching at UCSD, call z2 the "z-progressive", following the Lopez's intuitions about sentences like (6), in contrast with the Definite in (2)-(3).

Only motion verbs exhibit both future Definite and z2 forms; all other verbs only have the future Definite. However, in most Zapotec languages forms of 'go' and 'come' can be incorporated at the front of a verb stem, following the aspect prefix, forming "andative" and "venitive" verb forms, which can also appear with both types of $z$ - prefixes. All other derivatives of 'go' and 'come', such as 'bring'/'take' verbs, also have both forms. (I won't discuss these derived forms in this paper.)

\section{Lee's Analysis}

Lee (2006) writes that the Definite "can express either emphatic future readings [as in (2)] or incomplete events in the immediate past [as in (6)]" (201); "while past events expressed with Perfective verbs are understood as being fully completed at UT [utterance time], those expressed with Definite verbs are interpreted as being initiated, but not yet fully culminated" (260). Her sophisticated analysis of the syntax of these verbs considers their behavior both as matrix verbs and when embedded under verbs of saying; she argues that both represent the same aspect, with a modal meaning of necessity, thus suggesting an insightful way to reconcile the seemingly disparate meanings of the $z$-verbs in (2)-(3) and (6).

... Definite-marked verbs (on both their future and non-future readings) describe events that haven't been completed yet, but are strongly believed by speakers to be inevitable: in the future Definite case, the event described has not begun yet, but the speaker emphatically believes it will occur; in the non-future case, the event is believed by the speaker to have been initiated, but not yet completed (and the eventual completion of the event is assumed). (p. 263)

...the future and non-future Definite are, despite their differences in temporal interpretation, manifestations of the same aspect and not merely different aspects that accidentally resemble each other. (p. 266)

\section{The Problem}

However, z2 forms have a considerably wider range of uses than is illustrated in

\footnotetext{
${ }^{4}$ Alas, Munro and Lopez et al. (1999) also somewhat inconsistently use the term 'realis Definite'.
} 
(6), especially in texts. First, Munro and Lopez et al. (1999) cite z2 forms that express punctual rather than progressive events, such as (7):

$$
\begin{aligned}
& \text { Chih b-raguèe'll=ih, } \quad \text { z-eèe'=ëng No'rt. } \\
& \text { when perf-be.next.day=3s.dst } \quad \text { z2-go=3s.prx North } \\
& \text { 'When the next day came (i.e., when it was the next day), } \\
& \text { he went to the United States.' }
\end{aligned}
$$

This does not seem like an incomplete event in the immediate past (as (6) might be); the speaker is describing events that occurred years ago.

(7) is taken from a 200-page collection of TVZ narratives about the immigration experience (Lopez and Munro, eds., in preparation) that provides many examples of z2 verbs, as well as some future Definites of motion verbs, such as (8), where the 'surely' sense of the Definite is contrasted with the less certain Irrealis, or (9)-(10), which are additional punctual past examples.

$$
\begin{aligned}
& \text { Lla'az=a' dàa'ru' } \quad \mathrm{g}-\mathrm{ya}^{\prime}=\mathrm{a}^{\prime}, \quad \text { sye'mmr } \quad \mathbf{z}-\mathbf{y a} \mathbf{a}^{\prime}=\mathrm{a}^{\prime} \text {, } \\
& \text { neut?.think some.day irr-go.home }=1 \mathrm{~s} \text { always def-go.home }=1 \mathrm{~s} \\
& \text { pehr nyèe'c nà }=a^{\prime} \quad \text { que'ity } r \text {-ahcbiì }=a^{\prime} \text { uu'c } \\
& \text { but even pron=1s not hab-know }=1 \mathrm{~s} \text { when } \\
& \text { g-ya'=a', nih } \quad \mathrm{g} \text {-ya' }=\mathrm{t}=\mathrm{a}^{\prime} \quad \text { ba'i. } \\
& \text { irr-go.home }=1 \mathrm{~s} \text { that irr-go.home }=\mathrm{emph}=1 \mathrm{~s} \text { well }
\end{aligned}
$$

\begin{tabular}{|c|c|c|c|}
\hline $\begin{array}{l}\text { Chiru' nnah } \\
\text { then neut.say } \\
\text { z-e'=ùu'?' } \\
\text { z2-go=2s.inf }\end{array}$ & $\begin{array}{l}\begin{array}{l}\text { supervisor } \\
\text { supervisor }\end{array} \quad \text { of }=1 \mathrm{e}=1 \mathrm{~s}=\mathrm{a} \text { ', } \\
\text { nnà=ih, }\end{array}$ & $\begin{array}{l}\text { 'Xi ni'ih } \\
\text { what for } \\
\text { r-e'ipy=a' } \\
\text { hab-tell }=1 \mathrm{~s}\end{array}$ & $\begin{array}{l}\mathrm{a} \\
\text { already } \\
\text { la'a=i } \\
\text { pron=3s.dst }\end{array}$ \\
\hline $\begin{array}{l}\text { zi'cy } \text { g-uhc } \\
\text { thus perf-be }\end{array}$ & $\begin{array}{l}\text { niih } \quad \mathbf{z}-\mathbf{a}^{\prime}=\mathbf{a}^{\prime} . \\
\text { that } \\
\mathrm{z} 2-\mathrm{go}=1 \mathrm{~s}\end{array}$ & & \\
\hline
\end{tabular}

'I thought that some day I would go home, I would surely go home for good, but I didn't know when I would go back, go back for good.'

$$
\begin{array}{lllll}
\text { Pehr ra bzyaàa'n=ëng, } & \text { ra bèe'll=ëng, } & \text { pehr } \\
\text { as.for pl opp.sex.sib=3s.prx } & \text { pl sister.w.s=3s.prx } & \text { as.for } \\
\text { nyèe'c=za' } & \text { làa'=rih } & \text { que'ity g-àann=rih } & \text { càa nehehz } \\
\text { even=wow } & \text { pron=3p.prx } & \text { not } & \text { irr-know=3p.dst } & \text { where way } \\
\text { canzaa } & \text { x:ta'ad=rih; } & \text { z-èe=ta' } & \text { bùunny=ih. } \\
\text { neut.wander } & \text { poss-father=3p.prx } & \text { z2-go=emph } & \text { person=that }
\end{array}
$$

'As for her brothers and sisters, even they don't know where their father went off to; that person just left.'

"Then my supervisor said, "Why did you go?" he said, so I told him how it was that I left.'

As (9)-(10) show, z2 'go' sentences without a directional object are often translated with 'leave'.

Z2 verbs may also express ofther aspectual notions. For example, my collabo- 
rator Felipe Lopez feels that the Perfective and z2 verbs in (11)a-b could replace each other. Perfective $b$-ie'd in (a) could be z2 z-i'ìe'd, and z2 z-i'ìe'd=ëng in (b) could be Perfective $b$-ie'd=ëng:
a. - Xi iihahz b-ìe'd Cho'nn re'nn nah?... what year prf-come Chona here now 'What year did Chona come here, now?'
b. - Loh sete'nntayseiz $\mathbf{z}-\mathbf{i}^{\prime} \mathbf{i e} \mathbf{e}^{\mathbf{d}}=\mathbf{e} \mathbf{n}$ g. in seventy.six z2-come $=3$ s.prx 'She came in seventy-six.'

Similarly, the z2 verb in (12), in which a narrator discusses the behavior of young immigrants returning to Oaxaca, could be replaced by a Habitual verb:

$\begin{array}{cllll}\text { Chih } \quad \text { z-i'ì'd=rih } & \text { laad } & \text { rèe' } & \text { àa'? } & \text { A } \\ \text { when z2-come=3p.dst } & \text { side } & \text { here } & \text { what.about } & \text { already } \\ \text { b-chùu=rih } & \text { ba'i. } & & & \\ \text { prf-change=3p.dst } & \text { well } & & & \end{array}$

'And when they come back here? They've really changed.'

(z-i'ìe'd=rih could be Habitual $r$-ie'd=rih)

The narratives also contain $\mathrm{z} 2$ forms whose meaning seems clearly progressive (describing ongoing motion), much like the elicited example (6):

$$
\begin{aligned}
& \begin{array}{lllll}
\text { R-e'ipy=a' } & \text { làa'=rih } & \text { nehz.ahg.zahgu=ih } & \text { a } & \mathbf{z - a} \mathbf{a}^{\prime}=\mathrm{a}^{\prime} . \\
\text { hab-tell=1s } & \text { pron=3p.dst } & \text { way.just=that } & \text { already } & \mathrm{z2} \text {-go=1s }
\end{array} \\
& \text { 'Tòo', nnah=rih, 'tye'nn g-uuny=ùu' compa'anny' - } \\
& \text { let's.go neut.say }=3 \text { p.dst so.that irr-do }=2 \text { s.inf company } \\
& \text { zi'cy nih } \mathrm{r} \text {-chàag=za' ra mnì'ny sa'=nii'. } \\
& \text { thus rel hab-meet=wow pl kid fellow=anap }
\end{aligned}
$$

Of course, cross-linguistically progressives of motion verbs often develop into future expressions, which may explain why (14) below seems to have a somewhat less ongoing, more future reference. In fact, other $\mathrm{z} 2$ verbs sometimes express unaccomplished notions that are more clearly neither present nor past, as in (15), whose z2 form. Lopez feels, could be replaced by an Irrealis verb (though not by a future Definite). 
Pamela Munro

(14)

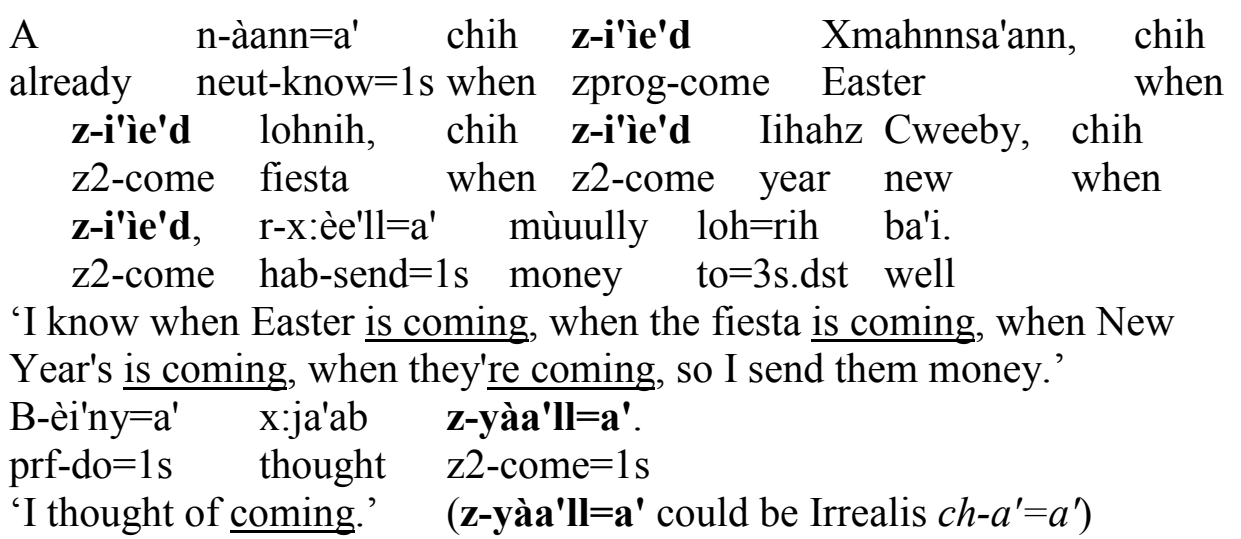

Other apparently "modal" (or as I would rather say "non-actual", following Chung and Timberlake 1986) notions expressed by z2 verbs are seen in

$$
\begin{array}{clll}
\text { Mahssuu z-èe fami'lly, } & \text { lla'az=a', pehr } & \text { que'ity=zhy=a' } \\
\text { even.if z2-go wife } & \text { neut?.think=1s but not=must=1s } & \text { ch-ie=rëng. Chingaad, mejoor zèèiny } \\
\text { n-daà=a' làa'=rëng } & \text { ch-ie=rên } \\
\text { sbj-let=1s pron=3p.prx } & \text { irr-go=3p.prx damn better work } \\
\text { g-uuny=a' } & \text { y-sàa'=a' } & \text { lahty ch-u'=rëng } & \text { ba'i. } \\
\text { irr-do=1s irr-make=1s } & \text { place irr=be.in=3p.prx } & \text { well. }
\end{array}
$$

'Even if [my] wife leaves, I think, even then I wouldn't let them [my children] go. Damn, I'd rather work in order to have a place for them to live.'

Nii nàa te'ihby rrepo'rt nih ca-lde's $=$ ih, nnah=rih, that cop one report rel prg-lift=3s.dst neut.say $=3 \mathrm{p} . \mathrm{dst}$

$\begin{array}{llllll}\text { tye'nn } & \text { pahr } & \text { a } & \mathbf{z}-\mathbf{y o o}^{\prime}=\text { ëhnn } & \text { pahrtra's } & \text { steeby. } \\ \text { because } & \text { for } & \text { already } & \text { z2-go.home }=1 p & \text { back } & \text { again }\end{array}$

'That was a report that he was making, they said, so that we could go back again.'

(18) Chiru' dannoo=ëhnn tèe'gwag xi rsoon=di' ba'i chiru' then pron $=1 \mathrm{p}$ neg what message $=\mathrm{pt}$ well then

$$
\begin{aligned}
& \text { làa'=rëb cay-u'=rëb gahllrzyàa' dannoo=ëhnn càa } \\
& \text { pron=3p.rsp prg-be.in=3p.rsp worry pron=1p where } \\
& \text { nehz } \mathbf{z - o o}=\text { ëhnn vaya cëhmm nàadìi'zh zèi'ny }=\mathrm{ih} \\
& \text { way } \mathrm{z} 2-\mathrm{go}=1 \mathrm{p} \text { well because supposed.to work }=3 \text { s.dst }
\end{aligned}
$$

zòo'nn vaya.

$\mathrm{z} 2-\mathrm{go}=1 \mathrm{p}$ well

'At that point we had [sent] no messages, so they must have been worrying about us, where we had gone, because we were supposed to be going to work.'

Crucially, it seems, non-actual z2 verbs like these either convey the idea of 
progressive ideas in the future, as in the second z2 form in (18) (and possibly also (14)), or refer to possibility rather than necessity (as in (16) and (17)).

\section{Comparative Data}

A number of other Zapotec languages appear to have cognates of both types of TVZ $z$ - forms; I will note here only data from two closely related Valley Zapotec languages, ${ }^{5}$ and from one quite distantly related language. ${ }^{6}$

Adam (2003:69; glosses adapted) writes that in Santo Domingo Albarradas Zapotec (Dihidzx Bilyáhab) "The definite ${ }^{7}$ is used in any tense to convey a pending action or event", but also "Another one of the definite's uses is to show incompletion of an act of 'going' which has already begun as opposed to the perfective which shows completion of the act of 'going' with a 'return"' (70). However, the same aspect prefix is also used in apparently punctual textual examples like

$$
\begin{aligned}
& \text { Z-é=b } \quad \text { zhan nejez=gin } \text { g-ijti=b. } \\
& \text { def-go=an butt road=dct perf-die=an } \\
& \text { 'He fell down below that road and died.' (Adam 2003:249 and p.c. 2007) }
\end{aligned}
$$

Adam (p.c.) has confirmed to me that these two "definite" forms are at least sometimes morphologically distinct, with the cognate of the future Definite form in (20)a and that of the $\mathrm{z} 2$ verb in (20)b:

$$
\begin{aligned}
& \text { a. future Definite } \mathbf{z - e j}|\mathbf{e}|=\mathbf{z h} \quad \text { in } z-e j|e|=z h \text { yá 'will he go?' } \\
& \text { b. z2 z-ée=zh in má } z \text {-ée }=z h \text { yá? } \\
& \text { 'did he already start going?' }
\end{aligned}
$$

As in TVZ, the future Definite may be used with (virtually) any verb, while the z2 form is restricted to a small class of motion verbs.

López Cruz (1997; glosses adapted) analyzes the San Pablo Güilá Zapotec cognate of the future Definite in (21)a as the "futuro" and the cognate of the z2 verb in (21)b as an allomorph of the "progresivo":

$$
\begin{aligned}
& \text { a. s-yéed Jwâany là'ф } \\
& \text { def-come Juan field } \\
& \text { 'Juan vendrá al campo [Juan will come to the field].' (p. 90) }
\end{aligned}
$$

\footnotetext{
${ }^{5}$ I cannot discuss here data from another closely related Valley language, Santa Ana del Valle Zapotec, kindly provided by Rosa María Rojas Torres, which seems in line with the Adam and López Cruz data summarized below.

${ }^{6}$ There are also apparently two distinct $z$ - forms in the Colonial Valley Zapotec descriptions by Córdova (1578a, 1578b).

${ }^{7}$ Adam now refers to this form as "Alethic", p.c. 2007.
} 
Pamela Munro

b. s-yeed Jwâany là' $\not$
z2-come Juan field
'Juan viene al campo [Juan comes/is coming to the field].' (p. 89)

As (21) shows, these forms are morphologically distinct:. López Cruz's data also shows that "progresivo" forms of motion verbs can have a punctual sense (again often suggesting one-way motion), ${ }^{8}$ as in

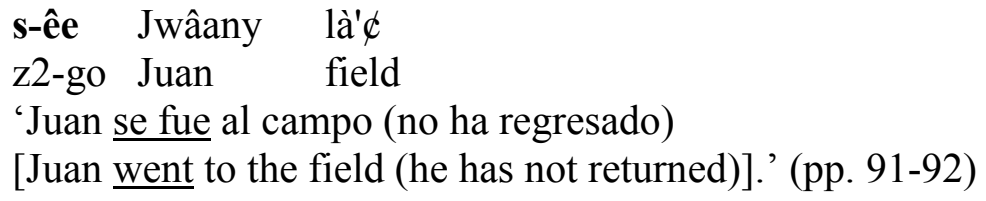

Finally, Black (2004) identifies two separate cognate aspects in Quiegolani Zapotec (a much more distantly related language of the Southern branch of Zapotecan), a special $z$ - prefix "used to express progressive action" with verbs of motion (2004:27), such as those in ((23)) (p.c. 2007), and an $s$ - Future prefix that can be used with a wider range of verbs (2004:19), again including the motion verbs, as in ((24)) (p.c. 2007):

z-a (progressive, 'go away from base' [cf. TVZ 'go'])

z-ya (progressive, 'go to base' [cf. TVZ 'go home'])

s-a (Future, 'go away from base')

s-ya (Future, 'go to base')

\section{Are There Two z- Aspects, or One?}

\section{1 .}

The z2 usage only occurs with a few verbs of motion and their derivatives, while the future Definite occurs with (almost) every verb. The comparative data, particularly from languages as distantly related as Quiegolani, supports the idea that this situation is quite archaic.

If the z2 usage is just another manifestation of the same aspect as the future Definite, why should this very different z2 usage occur only with a small and semantically restricted group of verbs, in so many languages? There seems to be no explanation of why the very different z2 usage - even if related — should be restricted to a small group of motion verbs. ${ }^{9}$

\section{2 .}

While the future Definite is a "modal" aspect, used to refer only to non-actual events, most z2 uses refer to actual events in the present or past and thus do not

\footnotetext{
${ }^{8}$ López Cruz (1997:91-92) also mentions two additional forms of 'ir' which she suggests may be additional aspects; these look like forms of TVZ 'goes home'.

${ }^{9}$ Bernard Comrie and Alexandra Aikhenvald reminded me during the discussion at BLS of special aspectual uses of motion verbs. So maybe this is not as unexpected as all that.
} 
seem "modal". While there may be a connection between non-actuality and incompleteness, many z2 usages with non-future reference do not describe incomplete events. There doesn't seem to be anything incomplete about the z2 examples like (7), (9)-(10), or the first z2 form in (18), or several others here. These don't seem to fit Lee's notion of "initiated but not fully culminated". However, they might be amenable to a different sense of "incompletive" like that described for the Mayan language Mam by England (2007), since punctual z2 forms generally occur in texts, where they serve to advance a narrative that (when the forms are used) is not yet complete. The lack of completion, then, is metalinguistic, and does not refer to the real-world status of the referenced event.

As we've seen above, z2 forms can be also used to refer to clearly "nonactual" events, as with (15)-(17), the second z2 form in (18), and perhaps also (14). As Lee $(1999,2006)$ makes clear and I discuss in Munro (2006), there is not a precise overlap between "modal aspect" and modal or non-actual reference. For example, the "non-modal" Perfective aspect is used for imperatives and can also refer to non-actual events to be completed in the future, as in

Yzh:ii chih y-zëhnny=a', al b-da'uhGye'eihlly.
tomorrow when irr-arrive=1s already perf-eat Mike
'When I arrive tomorrow, Mike will have already eaten.'
(Lee 2006:13, ex. 36)

But the contrast between the future Definite and the full range of both modal and non-modal uses of the $\mathrm{z} 2$ forms seems striking.

\section{3.}

Almost all $\mathrm{z} 2$ forms are pronounced slightly differently from corresponding Definite proper forms, as shown by a comparison of (2) vs. (6), or the paradigms in Table 1 on the next page. ${ }^{10}$ However, the first person forms, both singular and plural, are the same for both the future Definite and z2 in each case. As other Zapotec specialists know, first person forms tend to be irregular in a variety of ways (note that the first person stems of all three verbs are quite aberrant in these and all other aspects; those of 'comes', in particular, are fully suppletive).

Although it might be clearer that there were two separate aspects if all the forms were distinguished, Zapotec tolerates a high degree of homophony and near homophony (for example, many verbs that are distinguished in the Habitual are neutralized in the Perfective; conversely, 'goes' and 'goes home' are identical in the Habitual but differentiated in every other aspect). There would be no explanation for the differences shown in Table 1 if the future Definite and z2 forms were the same aspect.

10 TVZ distinguishes six third persons (proximate, distal, respectful, animal, familiar, and reverential; cf. Munro 2002). Second person formal forms and third person plural forms, whcih tend to be more regular, are not shown in the table, but all of them distinguish the future Definite and $\mathrm{z} 2$ forms. 


\section{Pamela Munro}

Table 1. Future Definite and z2 Forms of Three TVZ Motion Verbs

\begin{tabular}{|c|c|c|c|c|c|c|}
\hline$h a b$ & \multicolumn{2}{|c|}{ rihah 'goes' } & \multicolumn{2}{|c|}{ rihah 'goes home' } & \multicolumn{2}{|c|}{ rìe'd 'comes' } \\
\hline & $\begin{array}{c}\text { future } \\
\text { Definite }\end{array}$ & $z 2$ & $\begin{array}{l}\text { future } \\
\text { Definite }\end{array}$ & $z 2$ & $\begin{array}{l}\text { future } \\
\text { Definite }\end{array}$ & $z 2$ \\
\hline def & zeheh & zèe & zihah & ziia & zìe'd & zi'ie'd \\
\hline $1 s$ & \multicolumn{2}{|c|}{ za'a' $^{\prime}$} & \multicolumn{2}{|c|}{ zya'a' } & \multicolumn{2}{|c|}{ zyàa'lla' } \\
\hline $2 \operatorname{sinf}$ & zèu' & ze'ùu' & zìu' & zi'ùu' & zìe'dùu' & zi'ìe'dùu' \\
\hline $3 \operatorname{sprx}$ & zèe'ëng & zeèe'ëng & zyèe'ëng & zyeèe'ëng & zìe'dëng & zi'ìe'dëng \\
\hline $3 s d s t$ & zèèi' & ze'èi' & zyèèi' & zi'èi' & zìe'dih & zi'ìe'dih \\
\hline $3 s r s p$ & zehëhb & zeeëhb & zyiehëhb & zieëhb & zìe'dëhb & zi'ìe'dëhb \\
\hline $3 \operatorname{san}$ & zehëhmm & ze'ëhmm & zyiehëhmm & zye'ëhmm & zìe'dëhmm & zi'ìe'dëhmm \\
\hline 3 sfam & zehahzh: & zeeahzh: & zyiehahzh: & zieahzh: & zìe'dahzh: & zi'ìe'dahzh: \\
\hline 3 srev & zehihny & zeihny & zyiehihny & zyieihny & zìe'dihny & zi'ìe'dihny \\
\hline $1 p$ & \multicolumn{2}{|c|}{ zoo'ëhnn } & \multicolumn{2}{|c|}{ zyoo'ëhnn } & \multicolumn{2}{|c|}{ zyoo'pëhnn } \\
\hline $2 p \operatorname{pinf}$ & zehahd & zeeahd & zyiehahd & zieahd & zìe'dahd & zi'ìe'dahd \\
\hline
\end{tabular}

\section{4 .}

The z2 verb lacks certain structural peculiarities of the future Definite.

First, sentences with z2 verbs may be negated (26), while, as Lee (2006:261) notes, future Definite verbs 'are dispreferred in clausal negation constructions' :

Que'ity z-èe=dy=ëng Jwaany ri'cy nài'.
neg $\quad$ z2-go=pt=3s.prx Juan
'Juan didn't go there yesterday.'
*Que'ity z-eheh=di' Jwaany ricy zhii.
neg def-go=pt Juan there tomorrow
'Juan will definitely not go there tomorrow.'

Second, as Lee (2006:261-62) reports, the $\mathrm{z} 2$ form allows standard focus fronting $^{11}$ (28), while the future Definite does not (29):

\footnotetext{
the verb. Lopez feels that the (ii) construction is strongly contrastive.

(i) Jwaany, z-eheh Jwaany Ba'ahc. 'Juan, he will surely go to Tlacolula' Juan def-go Juan Tlacolula

(ii) Jwaany... $\quad$ z-eheh Ba'ahc. 'JUAN...will surely go to Tlacolula' Juan def-go Tlacolula
}

11 Instead of future Definite sentences like (29)a, my collaborator Felipe Lopez prefers topic constructions like (i) or the variant focus construction in (ii). Like a topic structure, but unlike a standard focus sentence, the variant focus construction (ii) has a noticeable pause following the initial constituent; unlike the topic structure, however, there is no resumptive element following 

a. Jwaany z-èe Ba'ahc. 'JUAN was going to Tlacolula.' Juan z2-go Tlacolula (cf. (6))
b. Ba'ahc z-èe Jwaany. 'Juan was going to TLACOLULA.' Tlacolula z2-go Juan
a. *Jwaany z-eheh Ba'ahc. 'JUAN will surely go to Tlacolula.' Juan def-go Tlacolula (cf. (2))
b. *Ba'ahc z-eheh Jwaany. 'Juan will surely go to TLACOLULA.' Tlacolula def-go Juan

Lee proposes a plausible structural explanation for these differences, but it's not clear that it requires that the two verb forms in question be the same.

\section{5 .}

Thus, there seem to be good reasons to distinguish the future Definite from the $z 2$ form, which is only used with three verbs of motion and which has a much wider range of both temporal and modal interpretations than the Definite. Certainly the semantics of the $\mathrm{z} 2$ form are complex, and worthy of further study: while it often overlaps with other aspects, speakers use it for particular effect, especially in narrative.

The question of what to call the $\mathrm{z} 2$ form remains. "Progressive" no longer seems appropriate, at least for TVZ (more comparative work is needed to discover whether languages like Quiegolani and SPGZ have a similar range of uses for their cognate forms, and thus what the use of the ancestor of all these forms might have been). A term like "Incomplete Motion" might seem appropriate for the TVZ form, but is a bit unweildy for us to use in our textbook (Munro, Lillehaugen, and Lopez in preparation). We've decided, therefore, to call this form the Incompletive, a name that pays tribute to Lee's analysis (though we reject the notion that this form is just another use of the Definite) - but a name which can only be understood through an insight like that England proposed concerning aspect in Mam.

\section{References}

Adam, Christopher C. 2003. A Study of Dihidx Bilyáhab (Santo Domingo Albarradas Zapotec) Morphophonology. MA Thesis, CSU Northridge.

Black, Cheryl A. 2004. Quiegolani Zapotec Syntax: A Principles and Parameters Account. Dallas: SIL International - University of Texas at Arlington.

Chung, Sandra, and Alan H. Timberlake. 1985. Tense, Aspect, and Mood. In Language Typology and Syntactic Description, ed. Timothy Shopen, vol. III, Grammatical Categories and the Lexicon, 202-258. Cambridge - New York: Cambridge University Press.

Córdova, Fr. Juan de. 1987 [1578a]. Vocabulario en lengua çapoteca. México: Ediciones Toledo (INAH). 
Córdova, Fr. Juan de. 1886 [1578b]. Arte del idioma zapoteco. Morelia: Imprenta del Gobierno.

England, Nora C. 2007. Marking Aspect and Mood and Inferring Time in Mam (Mayan). Presented at BLS 33.

Lee, Felicia A. 1999. Antisymmetry and the Syntax of San Lucas Quiavini Zapotec. Ph.D. dissertation, UCLA.

Lee, Felicia. 2006. Remnant Raising and VSO Clausal Architecture. Dordrecht: Springer.

Lopez, Felipe H., and Pamela Munro, eds. In preparation. X:a Mo'od Bie'd Ra Bùunny Sann Lu'uc Lohs Aa'nngl: Zapotec Immigration Narratives [How People of San Lucas Came to Los Angeles].

López Cruz, Ausencia. 1997. Morfología verbal del zapoteco de San Pablo Güilá. Tesis (licenciada en lingüística), Escuela Nacional de Antropología e Historia, México, D. F.

Munro, Pamela. 2002. Hierarchical Pronouns in Discourse: Third Person Pronouns in San Lucas Quiaviní Zapotec Narratives. Southwest Journal of Linguistics 21: 37-66.

Munro, Pamela. 2006. Modal Expression in Valley Zapotec. In William Frawley, ed., The Expression of Modality. Berlin/New York: Mouton de Gruyter, 173205.

Munro, Pamela, Brook Danielle Lillehaugen, and Felipe H. Lopez. In preparation. Cali Chiu? A Course in Valley Zapotec.

Munro, Pamela, and Felipe H. Lopez, with Olivia V. Méndez [Martínez], Rodrigo Garcia, and Michael R. Galant. 1999. Di'csyonaary X:tèe'n Dii'zh Sah Sann Lu'uc (San Lucas Quiaviní Zapotec Dictionary / Diccionario Zapoteco de San Lucas Quiaviní). Los Angeles: (UCLA) Chicano Studies Research Center Publications. 